Огляди літератури, оригінальні дослідження, погляд на проблему, випадок з практики, короткі повідомлення УДК 612.62.- 018.26-02:618.17: 612. 621. $31-053.7 / .86$

DOI 10.11603/1811-2471.2020.v.i2.11312

\title{
АНАЛІЗ МОРФОЛОГІЧНИХ ЗМІН СЛИЗОВОЇ ОБОЛОНКИ СЕЧОВОГО МІХУРА ЖІНОК РАННЬОГО ТА ПІЗНЬОГО МЕНОПАУЗАЛЬНОГО ПЕРІОДІВ ЗАЛЕЖНО ВІД ГОРМОНАЛЬНОГО СТАТУСУ
}

\author{
○Б. Ю. Бідованець' Я. Я. Боднарㄹ, Т. К. Головата², А. М. Пришляк² \\ ${ }^{1}$ Комунальне некомерційне підприємство «Тернопільський обласний клінічний онкологічний диспансер» \\ Тернопільської обласної ради \\ ${ }^{2}$ Тернопільський начіональний медичний університет імені І. Я. Горбачевського МОз України
}

PEзЮMЕ. На сьогодні дизурія у жінок перименопаузального періоду є однією із найсерйозніших проблем медицини. Тісний анатомо-функціональний зв'язок сечової системи із репродуктивними органами жінок та їх нейроендокринною системою потребує застосування комплексних методів дослідження у випадках різних патологічних станів, у тому числі зумовлених віковими змінами жіночого організму.

Мета - вивчення морфологічних змін слизової оболонки сечового міхура у жінок раннього та пізнього менопаузального періодів та їх залежність від рівнів прогестерону та естрадіолу.

Матеріал і методи. Досліджено біоптати слизової оболонки сечового міхура в ділянці трикутника та лівої бокової стінки у 62 жінок. 3 них до групи пацієнток раннього менопаузального періоду віднесено 20, пізнього менопаузального періоду - 28 пацієнток. Контрольну групу складали 14 жінок репродуктивного періоду в віці 35-45 років. Застосовані гістологічний та біохімічний методи дослідження.

Результати. Доведено, що в слизовій оболонці сечового міхура при дизурії у жінок перименопаузального періоду виникають виразні дистрофічні та дегенеративні пошкодження, які супроводжуються запальними реакціями у власній пластинці та компенсаторними гіперпластичними процесами. Рівень гормонів прогресивно знижується в обох групах пацієнток порівняно з групою контролю.

Висновки. У обстежених жінок раннього та пізнього менопаузального періодів рівень зниження гормонів має пряму відповідність із ступенем вираження морфологічних проявів.

КЛючОВІ СЛОВА: морфологія слизової оболонки сечового міхура; ранній і пізній менопаузальні періоди; прогестерон; естрадіол.

Вступ. У зв'язку зі збільшенням очікуваної тривалості життя на сьогоднішній день менопаузу необхідно розглядати (МП) як явище, яке настає у середині життя жінки, а не наприкінці, як це вважалося колись. Це, в свою чергу, потребує ранньої діагностики та своєчасного лікування симптомів, притаманних цьому періоду, що дозволяє значно покращити тривалість і якість життя, зберегти працездатність, запобігти незворотним патологічним змінам в організмі, які часто не піддаються навіть хірургічній корекції, нарешті, зекономити значні фінансові ресурси, враховуючи і невпинне зростання кількості населення, а отже, і частки людей похилого віку.

Під час II Всесвітньої асамблеї ООН із проблем старіння (8-12 квітня 2002 року, Мадрид, Іспанія) задекларовано [1], що у світі відбувається безпрецедентна зміна демографічної структури, i що до 2050 року кількість осіб віком понад 60 років зросте від 600 млн до майже 2 млрд, а частка осіб віком понад 60 років, як очікується, повинна подвоїтися, причому завдяки більшій тривалості життя у жінок їхня частка у гендерній структурі буде превалювати.

Урогенітальні (УГ) розлади (УГ естроґен-дефіцитний синдром, УГ атрофія) - симптомокомплекс з боку нижніх відділів сечостатевої системи, який виникає на ґрунті вираженого дефіциту естрогенів (ЕГ), частота і ступінь вираженості якого зростає з віком: якщо в 55-60 років скарги на УГ симптоми висловлюють $30 \%$ жінок, то після 75 років - близько $60-75$ \% [2, 3]. При опитуванні 970 жінок віком понад 18 років автори [4] виявили, що найчастіше порушення сечовипускання спостерігалося у віці після 45 років (у $61 \%$ ), у віці 40-45 років-у $23 \%$, і до 40 років -у $16 \%$, причому третина респонденток відмовилися відповідати, і лише $29 \%$ жінок своєчасно зверталися до лікарів. До 75 років вже 2/3 жінок турбують УГ розлади, а після 75 років складно зустріти жінку, в якої не спостерігалося 6 окремих симптомів із боку сечостатевої системи [5]. УГ розлади, що виникають переважно через 2-5 років після настання МП, пов'язані з атрофічними процесами, що розвиваються в сечостатевому тракті у зв'язку із прогресивним дефіцитом ЕГ $[6,7]$. Важливе значення мають анатомо-фізіологічні особливості, спадковість, гормональний фон тощо. Проте ця патологія у науковій літературі, зокрема у вітчизняній, згадується зрідка та фрагментарно. Проблема охоплює, як мінімум, дві галузі медицини і поглиблюється різним підходом до її вирішення.

Мета - з'ясувати морфофункціональні особливості сечового міхура у жінок перименопау- 
Огляди літератури, оригінальні дослідження, погляд на проблему, випадок з практики, короткі повідомлення

зального періоду та їх залежність від рівня основних статевих гормонів - прогестерону та естрадіолу.

Матеріал і методи дослідження. Робота проведена у клініці онкології та на кафедрі патологічної анатомії Тернопільського національного медичного університету імені І. Я. Горбачевського МОЗ України.

При поділі досліджуваних жінок на групи ми керувалися загальноприйнятою класифікацією періодів менопаузи: 45-51 рік - пременопауза, 51-52 роки - менопауза, понад 52 роки - постменопауза $[8,9]$.

Таким чином, жінок пременопаузального періоду та менопаузи ми віднесли до групи пацієнток раннього менопаузального періоду, яка склала 20 осіб. Групу жінок пізнього менопаузального періоду (понад 52 роки) склали 28 осіб. Контрольну групу склали 14 жінок репродуктивного періоду (35-45 років). Критеріями включення слугували жіноча стать, вік понад 35 років, інформована згода пацієнтки на проведення дослідження. Критеріямивиключення-наявністьендокринологічної, неврологічної, інфекційної, тяжкої серцевосудинної чи гастроентерологічної патології, запальних процесів сечостатевої системи, а також системних захворювань сполучної тканини, перенесені операції на гіпофізі, щитоподібній та надниркових залозах чи яєчниках, прийом гормональних препаратів протягом останніх 3 років, інвазивна форма онкогінекологічної патології, дисеміновані форми онкологічних захворювань.

Для проведення кількісного визначення прогестерону (ПГ) та естрадіолу (Е2) використовували набір реаґентів фірми «ХЕMA Co., Ltd.» для загальноприйнятих лабораторних методів дослідження $[10,11]$. Статистичну обробку отриманих показників проводили за допомогою програми Microsoft Excel, достовірність різниці між порівнюваними величинами визначали при нормальному розподілі за t-критерієм Student, в інших випадках - за допомогою U-критерію MannWhitney-Wilcoxon.

3 метою дослідження морфологічних особливостей сечового міхура в період менопаузи виконано біопсію його стінки у ділянках трикутника та бокової стінки у 62 жінок віком 35-74 роки. Огляд сечового міхура проводили цистоскопом Richard Wolf із тубусом 19,5F і телескопом із кутом заломлення $30^{\circ}$ і $70^{\circ}$, біопсію виконували жорсткими зігнутими ложкоподібними біопсійними щипцями із лівої бокової стінки та трикутника. Матеріал фіксували в 10 \% розчині формаліну, потім піддавали градуйованому спирту для дегідратації та вкладали в парафіновий віск. 3 парафінових блоків робили зрізи товщиною 4-5 мкм за допомогою мікротома MC-2. Для гістологічного дослідження зрізи тканин фарбували гематоксиліном (розчин Маєра) та еозином. Мікроскопічне вивчення проводили за допомогою мікроскопа Granum. Мікрофотографування зображень здійснювали за допомогою цифрової відеокамери Granum DSM 310. Фотографії обробляли за допомогою програми Toup View з метою виявлення загальної структури патологічних змін та гістотопографічних співвідношень між стромою і паренхімою, а також елементами мікроциркуляторного русла.

При виконанні роботи дотримані правила безпеки пацієнтів, збережені права та канони людської гідності, а також морально-етичні норми відповідно до основних положень GСР (1996 р.), Конвенції Ради Європи про права людини та біомедицину (від 04.04.1997р.), Гельсінської декларації Всесвітньої медичної асоціації про етичні принципи проведення наукових медичних досліджень за участю людини (1964-2000 рр.) і наказу МОЗ України № 281 від 01.11.2000 р., а також етичного кодексу вченого України (2009 р.).

Результати й обговорення. Відомо, що ЕГ недостатність $€$ другою за частотою і значимістю причиною розвитку гіперактивного сечового міхура. Більшість жінок віком понад 45 років вказують на збіг початку захворювання із настанням МП. Поширеність цього симптомокомплексу залежить від тривалості постменопаузи і збільшується з 30 \% жінок у 55-60 років до близько 6075 \% після 75 років, що пов'язують із наростанням ЕГ дефіциту, і як наслідок цього, з ішемією сечового міхура та атрофією уротелію [3].

Проведене нами лабораторне дослідження вмісту в крові основних гормонів показало, що рівень Е2 у жінок раннього менопаузального періоду недостовірно ( $>0,05)$ відрізнявся від показника контрольної групи на 4,7 \% - $(101,5 \pm 18,8)$ нг/л проти $(106,5 \pm 25,6)$ нг/л. Однак у жінок пізнього менопаузального періоду показник рівня Е2 на 47,5 \% знижувався, порівняно з контрольною групою, $(55,9 \pm 9,2)$ нг/л проти $(106,5 \pm 25), 6$ нг/л, та на 44,9 \% по відношенню до групи жінок раннього менопаузального періоду. Ці показники були статистично достовірні $(p<0,05)$ (рис. 1).

Значення рівня проґестерону (ПГ) прогресивно знижувалися залежно від віку (рис. 2). Так, показник у жінок першої групи спостереження був майже у 2 рази нижчий $(48,2 \%)$, ніж у контролі- $((2,6 \pm 0,4)$ нг/л проти $(5,4 \pm 1,2)$ нмоль/л $(p<0,05)$, а у другій групі рівень ПГ в крові знижувався майже в 3,5 раза $(64,8 \%)$ - до $(1,9 \pm 0,3)$ нмоль/л $(p<0,05)$.

Мікроскопічні зміни епітеліального покриву слизової оболонки сечового міхура у 1-й групі 
Огляди літератури, оригінальні дослідження, погляд на проблему, випадок з практики, короткі повідомлення

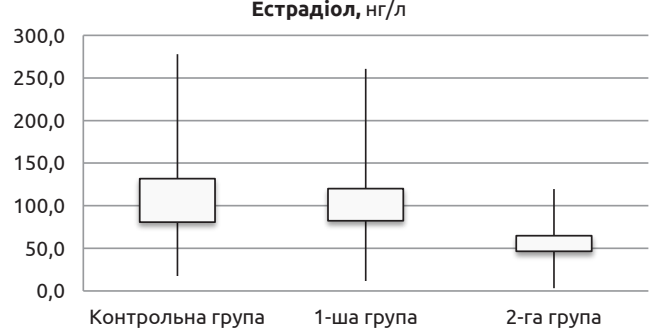

Рис. 1. Показники естрадіолу в жінок досліджуваних груп.

жінок на різних ділянках, навіть у межах одного випадку, були різними, але характерними для всіх випадків спостережень. Перехідний епітелій був нерівномірної товщини, місцями до утворення одного шару сплощених клітин та десквамації з утворенням дрібних або глибоких ерозій.

Власна пластинка слизової оболонки була потовщена, в ній визначалися різної інтенсивності лімфогістіоцитарні запальні інфільтрати $з$ домішками плазмоцитів, нейтрофільних і еозинофільних лейкоцитів і фібробластів із поширенням запалення на епітелій і підслизову основу (рис. 3).

У підслизовій основі виявляли набряк або лімфектазії, периваскулярну запальну інфільтрацію і проліферацію колагенових волокон, що призводили до ії̈ потовщення.

Описані структурні зміни супроводжувалися порушенням внутрішньоорганної гемодинаміки 3 різним ступенем вираження. Переважали дилатація вен і венул з їх повнокров'ям, стаз еритроцитів у субепітеліальних мікросудинах, утворення тромбів у дрібних венах поєднувалося з діапедезними крововиливами у всій товщі слизової оболонки і підслизового шару.

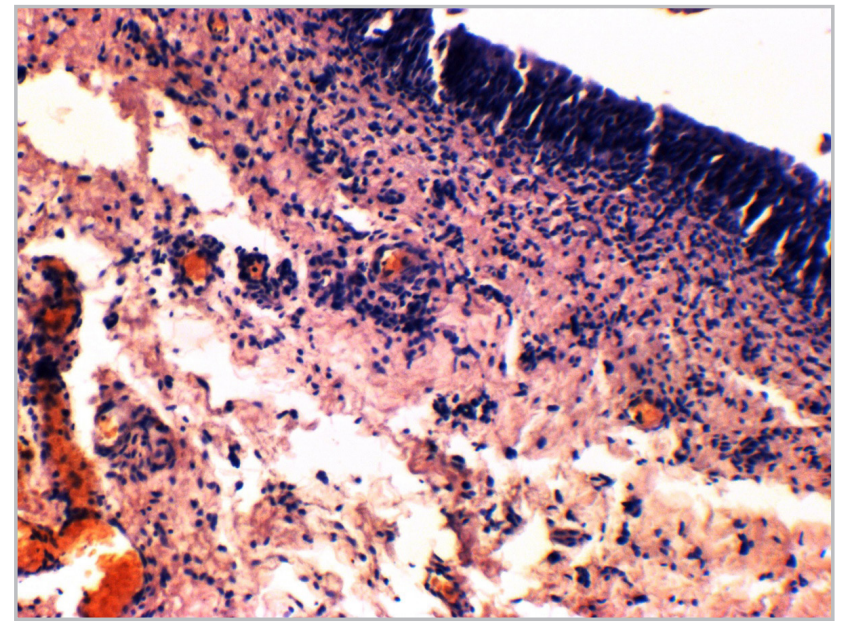

Рис. 3. Гіперплазія уротелію, повнокров'я судин підслизової основи та виражена запальна інфільтрація. Фрагмент слизової оболонки сечового міхура жінки першої групи дослідження. Забарвлення гематоксиліном і еозином. $\times 100$.

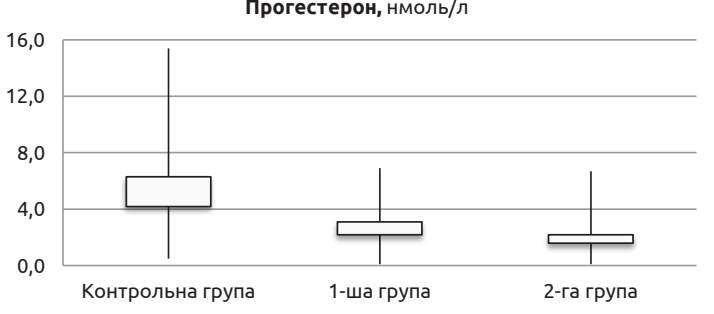

Рис. 2. Показники прогестерону в жінок досліджуваних груп.

У 5 випадках цієї групи в уротелії були виявлені доброякісні проліферативні і метапластичні зміни, гіперплазія уротелію зі збільшенням числа клітинних шарів. Нерідко зустрічалися осередки інвагінації уротелію у власну пластинку слизової оболонки - гнізда Брунна.

Аналіз гістоструктури слизової оболонки сечового міхура у жінок другої групи показав, що у більшості випадків домінантними ознаками ставали плоскоклітинна метаплазія перехідного епітелію з базальноклітинною проліферацією, вираженим акантозом, з гідропічною або кератогіаліновою дистрофією поряд із ерозіями, крововиливами та запальною інфільтрацією власного шару слизової оболонки сечового міхура та підлеглого підслизового шару (рис. 4).

Поглиблювалися та поширювалися розлади гемодинаміки - повнокров'я венул і вен, стаз еритроцитів у прекапілярах, крововиливи, тромбоз дрібних вен. Можна стверджувати, що подібні перманентні розлади кровообігу сприяли хронізації запального процесу, розвитку гіперпластичних та дегенеративних змін, склерозуванню власної пластинки слизової оболонки та підслизової основи.

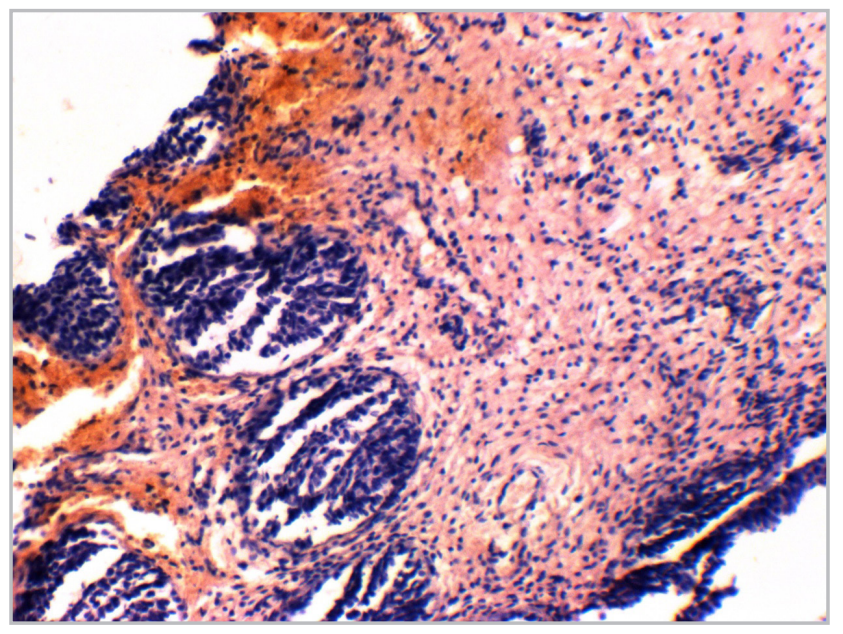

Рис. 4. Інвагінації уротелію в підслизову оболонку з утворенням гнізд Брунна, крововиливи. Фрагмент стінки сечового міхура жінки другої дослідної групи. Забарвлення гематоксиліном і еозином. ×200. 
Огляди літератури, оригінальні дослідження, погляд на проблему, випадок з практики, короткі повідомлення

Висновки. У слизовій оболонці сечового міхура жінок раннього та пізнього менопаузальних періодів за умови дизуричних розладів виникають прогресуючі запальні, деструктивні, дегенеративно-гіперпластичні та склеротичні зміни, які супроводжуються глибокими гемодинамічними розладами. Ступінь вираження морфологічних змін прямо залежить від рівня статевих гормонів.

\section{ЛІТЕРАТУРА}

1. Политическая декларация второй Всемирной ассамблеи по проблемам старения (8-12 апреля 2002 года, г. Мадрид, Испания) [Электронный ресурс] / Организация Объединенных Наций, - Режим доступа: https://www.un.org/ru/documents/decl_conv/ declarations/ageing_decl.shtml.

2. Местная терапия урогенитальных нарушений в пери- и постменопаузе / Т. В. Овсянникова, И. О. Макаров, Е. И. Боровкова, И. А. Куликов // Акушерство, гинекология и репродукция. - 2010. - Т. 4, № 3. - С. 25-28.

3. Кулаков В. И. Гинекология: национальное руководство / В. И. Кулаков, Г. М. Савельева, И. Б. Манухин. М. : ГЭОТАР-Медиа, 2009. - С. 462-469, 485-492.

4. Результаты эпидемиологического исследования распространения нарушений мочеиспускания у женщин / И. А. Аполихина, Ф. Н. Махмеджанова, В. Е. Балан, И. А. Курючкина // Гинекология. - 2012. - Т. 14, № 2. - С. 4-6.

5. Тихомиров А. Л. Урогенитальные расстройства в постменопаузе и заместительная гормонотерапия / А. Л. Тихомиров, Ч. Г. Олейник // Лечащий врач. - 2003. T. 7, № 3 .

\section{REFERENCES}

1. Political Declaration and Madrid International Plan of Action on Aging (Second World Assembly on Aging, Madrid, Spain, 8-12 of April, 2002). Retrieved from: https://www. un.org/en/events/pastevents/pdfs/Madrid_plan.pdf.

2. Ovsyannikova, T.V., Makarov, I.O., Borovkova, E.I., \& Kulikov, I.A. (2010). Mestnaya terapiya urogenitalnykh narusheniy v peri- i postmenopauze [The local therapy of urogenital disorders in peri- and postmenopause]. Akusherstvo, ginekologiya i reproduktsiya - Obstetrics, Gynecology and Reproduction, 4 (3), 25-28 [in Russian].

3. Kulakov, V.I., Savelieva, G.M., \& Manukhin, I.B. (2009). Ginekologiya: natsionalnoe rukovodstvo [Gynecology: National guideline]. Moscow: GEOTAR-Media [in Russian].

4. Apolikhina, I.A., Makhmedzhanova, F.N., Balan, V.E., \& Kuriuchkina, I.A. (2012). Rezultaty epidemiologicheskogo issledovaniya rasprostraneniya narusheniy mocheispuskaniya u zhenshchin [The results of the epidemiology study of urination disorders in women]. Ginekologiya - Gynecology, 14 (2), 4-6 [in Russian].

5. Tikhomirov, A.L., \& Oleinik, Ch.G. (2003). Urogenitalnye rasstroystva $\mathrm{v}$ postmenopauze i zamestitelnaya
Перспективи подальших досліджень. Проведене дослідження морфологічно обґрунтовує доцільність застосування замісної гормонотерапії у жінок перименопаузального періоду та в постменопаузі для лікування УГ розладів, а також може бути основою для розробки препаратів, які покращують метаболізм та регенерацію уротелію в цієї категорії жінок. У перспективі - морфологічні дослідження стану слизової оболонки сечового міхура в умовах корекції.

6. Samsioe B. Urogenital aging-a hidden problem // Am. J. Obstet. Gynecol. - 2018. - Vol. 178, No. 5. - P. S245-S249.

7. Utian W.H. Menopause in modern perspective: a guide to clinical practice. - New York: Appleton-CenturyCrofts, 1980.

8. Серов В. Н. Гинекологическая эндокринология / В. Н. Серов, В. Н. Прилепская, Т. В. Овсянникова. - М. : Медпресс-информ, 2004. - С. 471-481.

9. Кулаков В. И. Гинекология : учебник для студентов медицинских вузов / В. И. Кулаков, В. Н. Серов, А. С. Гаспаров. - М. : ООО «Медицинское информационное агенство", 2005. - С. 394-397.

10. Прогестерон-ИФА: инструкция по применению набора реагентов для иммуноферментного определения прогестерона в сыворотке (плазме) крови / сост. Д. С. Кострикин [руков. службы клиентского сервиса ООО «ХЕМА»]. - ТУ №9398-036-18619450-2007. - Peгистр. удостов. № ФСР 2009/04162 от 20.02.2009 г. Document: K2071. - Instruction ver. 202. - Format ver. 011.

11. Estradiol ELISA: user`s manual [Text] / DRG instruments GmbH, Germany. - EIA-2693. - Ver. 11.0. - 09/2010.

gormonoterapiya [The urogenital disorders in postmenopause and the substitute hormone therapy]. Lechashchiy vrach - Treating Physician, 7 (3). Retrieved from: http:// www.lvrach.ru/2003/07/4530495 [in Russian].

6. Samsioe, B. (1998, May 01). Urogenital aging - a hidden problem. Am. J. Obstet. Gynecol, 178 (5), S245-249. DOI:10.1016/S0002-9378(98)70555-1.

7. Utian, W.H. (1980). Menopause in modern perspective. A guide to clinical practice. New York: Appleton-Century-Crofts.

8. Serov, V.N., Prilepskaia, V.N., \& Ovsiannikova, T.V. (2004). Ginekologicheskaya endokrinologiya [Gynecological endocrinology]. Moscow: Medpress-inform [in Russian].

9. Kulakov, V.I., Serov, V.N., \& Gasparov, A.S. (2005). Ginekologiya: uchebnik dlya studentov medytsynskikh vuzov [Gynecology: the textbook for medical students]. Moscow: LLC "Meditsynskoe informatsyonnoe agenstvo" [in Russian].

10. Progesteron-ELISA: the manual on reagents using for enzyme immunoassay detection of progesterone blood serum (plasma). Comp. by D.S. Kostrikin [the clinical service head of LLC "XEMA"]. Tech.Req. No. 9398-036- 
Огляди літератури, оригінальні дослідження, погляд на проблему, випадок з практики, короткі повідомлення 18619450-2007. - Reg.cert. FSR 2009/04162 of 11. Estradiol ELISA: user`s manual. DRG instruments GmbH, 20.02.2009. - Document: K2071. - Instruction ver. 202. - Germany. EIA-2693. Ver. 11.0. 09/2010.

Format ver. 011 [in Russian].

\title{
АНАЛИЗ МОРФОЛОГИЧЕСКИХ ИЗМЕНЕНИЙ СЛИЗИСТОЙ ОБОЛОЧКИ МОЧЕВОГО ПУЗЫРЯ ЖЕНЩИН РАННЕГО И ПОЗДНЕГО МЕНОПАУЗАЛЬНЫХ ПЕРИОДОВ В ЗАВИСИМОСТИ ОТ ГОРМОНАЛЬНОГО СТАТУСА
}

\author{
ФБ. Ю. Бидованец ${ }^{1}$, Я. Я. Боднар², Т. К. Головата², А. М. Пришляк² \\ ${ }^{1}$ Коммунальное некоммерческое предприятие «Тернопольский областной клинический онкологический \\ диспансер» Тернопольского областного совета \\ ${ }^{2}$ Тернопольский национальный медицинский университет имени И. Я. Горбачевского МОЗ Украины
}

\begin{abstract}
РЕЗЮМЕ. На сегодня дизурия у женщин перименопаузального периода составляет одну из наиболее серьезных проблем медицины. Тесная анатомо-функциональная связь мочевыводящей системы с репродуктивными органами женщин и их нейроэндокринной системой требует применения комплексных методов исследования в случаях разных патологических состояний, в том числе обусловленных возрастными изменениями женского организма.

Цель - исследование морфологических изменений слизистой оболочки мочевого пузыря у женщин раннего и позднего менопаузального периодов и их зависимость от уровней прогестерона и эстрадиола.

Материал и методы. Исследованы биоптаты слизистой оболочки мочевого пузыря в области треугольника и левой боковой стенки у 62 женщин. Из них к группе пациенток раннего менопаузального периода отнесено 20, позднего менопаузального периода - 28 пациенток. Контрольную группу составили 14 женщин репродуктивного периода в возрасте 35-45 лет. Применены гистологический и биохимический методы исследования.

Результаты. Доказано, что в слизистой оболочке мочевого пузыря при дизурии у женщин перименопаузального периода возникают отчетливые дистрофические и дегенеративные повреждения, которые сопровождаются воспалительными реакциями в собственной пластинке и компенсаторными гиперпластическими процессами. Уровень гормонов прогрессивно снижается в обеих группах пациенток в сравнении с группой контроля.

Выводы. У исследуемых женщин раннего та позднего менопаузального периодов уровень снижения гормонов имеет прямое соответствие со степенью выраженности морфологических проявлений.

КЛЮчЕВЫЕ СЛОВА: морфология слизистой оболочки мочевого пузыря; ранний и поздний менопаузальный периоды; прогестерон; эстрадиол.
\end{abstract}

\section{ANALYSIS OF MORPHOLOGICAL CHANGES OF THE BLADDER IN WOMEN OF EARLY AND LATE MENOPAUSAL PERIODS DEPENDING ON HORMONES}

\author{
@B. Yu. Bidovanets', Ya. Ya. Bodnar², T. K. Golovata², A. M. Pryshliak² \\ ${ }^{1}$ Municipal Non-Profit Institution of Ternopil Regional Council "Ternopil Regional Clinical Oncology Centre" \\ ${ }^{2}$ I. Horbachevsky Ternopil National Medical University
}

SUMMARY. Currently the dysuria in perimenopausal women is one of the most challenging issues in world health care. The close anatomical and functional relations of the female urinary system with reproductive organs and their neuroendocrine system cause the necessity of use of complex investigation methods of different pathologies including aging caused ones.

The aim - to study the morphological changes of the urinary bladder in women in early and late menopausal periods and their dependencies of the progesterone and estradiol levels.

Material and Methods. We studied the biopsy specimens of the urinary bladder mucosa taken from the trigon and lateral wall in 62 women. 20 patients were in early menopausal period, 28 were in late. 14 women $35-45$ years old were in the control group. We use histological and the biochemical study methods.

Results. We proved that in case of dysuria in perimenopausal women there are the distinct dystrophic and degenerative atterations in the urinary bladder mucosa. They are accompanied by inflammatory reactions in lamina propria and compensatory hyperplastic processes. The hormones' levels decreased progressively in both patients' groups in comparison to the control group.

Conclusion. The decrease of hormones' levels in women in early and late menopausal periods is directly corelated with the severity of morphology signs.

KEY WORDS: the morphology of the urinary bladder mucosa; early and late menopausal periods; progesterone; estradiol.

Отримано 12.06.2020 